\title{
Faktor-Faktor Yang Mempengaruhi Efektivitas Kelembagaan Petani (Kasus di Provinsi Jawa Tengah)
}

\author{
Efectivity of Famer's Institution and Their \\ Determinant's Factors \\ (Case: Province of Central Java)
}

\author{
Sapja Anantanyu ${ }^{1 *}$, Sumardjo $^{2}$, Margono Slamet ${ }^{2}$, dan Prabowo Tjitropranoto ${ }^{2}$ \\ ${ }^{1}$ Universitas Sebelas Maret Surakarta \\ ${ }^{2}$ Departemen Sains Komunikasi dan Pengembangan Masyarakat, \\ Fakultas Ekologi Manusia, Institut Pertanian Bogor
}

\begin{abstract}
The effectiveness farmer's institutions were needed for the agricultural development in globalization economic era. Economic indicators, agricultural infrastructures, and government policy often cause small farmer to economical and social marginalized. On the other side, farmer's institutions which are expected be able to strengthen the farmer position to face the existing problems not effectively yet. The purpose of this research are to: (1) Identify and explain various factors have affected on the effectiveness of farmer's institution, and (2) Formulate an appropriate strategy in capacity building of farmer's institution. This Research was conducted at three district of Center Java Province, there are: Klaten, Grobogan, and Karanganyar. The result shows that effectiveness of farmer's institution is still at medium category. Effectiveness of farmer's institution was directly influenced by level of member's participation in farmer's institution, outsider role, formal education, and local leadership. Famer's income, the quality of extension, social participation, needs, and capacities level of farmer were indirectly influenced to the effectiveness of farmer's institution by participation in farmer's institution. Learning experience of famer indirectly influences to the effectiveness of farmer's institution by capacities level of farmer. The quality of agricultural extension, directly and indirectly, influences to the farmer's capacities. It increases their participation in farmer's institution and push their institution effectiveness.
\end{abstract}

Key word: famer's institution, famer'capacity, famer's participation

\section{PENDAHULUAN}

Sektor pertanian di Indonesia memiliki potensi yang sangat besar untuk dikelola secara benar dan profesional agar mampu menyejahterakan masyarakat. Sektor pertanian dianggap penting karena sebagian besar penduduk hidup dari sektor pertanian, dari 95,5 juta penduduk Indonesia yang bekerja 42,05 persen bekerja di sektor pertanian (Statistik Indonesia, 2007). Wilayah Indonesia

\footnotetext{
* Korespondensi Penulis. Telepon: 8156737366

E-mail: sabjaanantanyu@yahoo.co.id
}

mempunyai 7,89 juta hektar lahan sawah, di samping itu masih ada 30,4 juta hektar hutan cadangan, 6,3 juta hektar rawa-rawa, 8,1 juta hektar tanah yang belum dimanfaatkan, dan 790 juta hektar laut. Penduduk yang besar (> 200 juta) merupakan pasar sekaligus potensi mengalami rawan pangan jika ketersediaan pangan terganggu. Pengembangan agrobisnis akan membuka peluang penciptaan tenaga kerja.

Pembangunan pertanian pada dasarnya meliputi pengembangan dan peningkatan pada faktor-faktor: teknologi, sumberdaya alam, 
Jurnal Penyuluhan, Maret 2009 Vol. 5 No. 1

sumberdaya manusia, dan kelembagaan (Uphoff, 1986). Usaha pertanian sendiri meliputi kegiatan-kegiatan input, produksi, dan out-put. Dalam pengelolaan faktor-faktor produksi, proses produksi, sampai dengan pengolahan hasil diperlukan kelembagaan petani. Pentingnya kelembagaan petani diakui dalam pembangunan pertanian, baik di negara industri maupun negara sedang berkembang seperti Indonesia. Namun kenyataan memperlihatkan kecenderungan masih lemahnya kelembagaan petani di negara berkembang, serta besarnya hambatan dalam menumbuhkan kelembagaan pada masyarakat petani. Kelembagaan petani diharapkan mampu membantu petani keluar dari persoalan kesenjangan ekonomi petani, namun sampai saat ini masih belum berfungsi secara optimal.

Globalisasi dan liberalisasi ekonomi sebagai implikasi diratifikasi GATT dan WTO merupakan kenyataan berat yang harus dihadapi oleh negara-negara berkembang, seperti Indonesia. Kenyataan yang harus diakui bahwa sektor pertanian di Indonesia sebagian besar dibangun oleh petani dengan unit usaha yang relatif sempit dengan kualitas sumberdaya manusia yang masih rendah. Keadaan pelaku usaha pertanian tersebut setiap tahun semakin bertambah jumlahnya dengan tingkat kesejahteraan yang masih rendah. Diperlukan penguasaan teknologi pertanian yang memadai dan kemampuan bersaing dari para petani agar mampu bertahan di tengah-tengah persaingan eko-nomi dunia. Upaya meningkatkan produk-tivitas, efisiensi usahatani, dan daya saing petani dilakukan melalui pengembangan kelembagaan pertanian, termasuk di dalamnya penguatan kapasitas kelembagaan petani.

Program-program pembangunan semakin sulit untuk menjangkau petani kecil secara individu yang jumlahnya sangat banyak. Situasi ekonomi yang ada, infrastruktur, serta kebijakan yang diciptakan oleh pemerintah seringkali mendorong petani-petani dengan lahan sempit dan buruh tani terdesak ke arah marginalisasi secara ekonomi dan sosial. Selain penguasaan atas lahan pertanian yang sempit, nilai tukar pertanian yang rendah, kebijakan pertanian yang tidak berpihak ke petani semakin mendorong terpuruknya petani ke dalam kemiskinan.

Terkait dengan permasalahan di atas, penelitian ini bertujuan untuk menjawab pertanyaan-pertanyaan sebagai berikut: (1) Sejauhmana tingkat efektivitas kelembagaan petani; dan (2) Faktor manakah yang berpengaruh penting terhadap tingkat efektivitas kelembagaan petani.

\section{METODE PENELITIAN}

Penelitian ini merupakan penelitian survei. Variabel-variabel utama yang terkait dengan pengembangan kelembagaan petani meliputi: $\left(\mathrm{X}_{1}\right)$ Status sosial ekonomi, $\left(\mathrm{X}_{2}\right)$ Kebutuhan petani, $\left(\mathrm{X}_{3}\right)$ Pengalaman belajar, $\left(\mathrm{X}_{4}\right)$ Kepemimpinan lokal, $\left(\mathrm{X}_{5}\right)$ Peran pihak luar, $\left(\mathrm{X}_{6}\right)$ Kualitas penyuluhan, $\left(\mathrm{Y}_{1}\right)$ Kapasitas petani, $\left(\mathrm{Y}_{2}\right)$ Partisipasi petani dalam kelembagaan, dan $\left(\mathrm{Y}_{3}\right)$ Efektivitas Kelembagaan Petani.

Penelitian ini dilakukan di tiga kabupaten Propinsi Jawa Tengah, yaitu: Kabupaten Klaten, Kabupaten Grobogan, dan Kabupaten Karanganyar. Secara keseluruhan penelitian dilakukan pada: 9 kecamatan, 27 desa, dan 70 kelompok tani. Populasi adalah petani yang tergabung dalam kelompok-kelompok tani. Penentuan sampel dilakukan dengan teknik stratified random sampling. Jumlah responden petani secara keseluruhan sebanyak 405 orang. Data dikumpulkan dari responden dengan menggunakan kuesioner. Selain itu wawancara terstruktur dengan tokoh masya-rakat, baik formal maupun non-formal, sebanyak 46 orang, serta wawancara mendalam dengan informan terpilih: kontak tani, pemuka masyarakat, dan dinas terkait. Validitas dan reliabilitas instrumen penelitian telah diuji sebelum digunakan, koefisien reliabilitas berkisar 0,663 - 0,997. Pendekatan analisis yang digunakan adalah deskriptif, secara kuantitatif maupun kualitatif, selanjutnya dilakukan uji statistik korelasi, regresi, dan analisis jalur. 
Jurnal Penyuluhan, Maret 2009 Vol. 5 No. 1

HASIL DAN PEMBAHASAN

\section{Profil Responden}

Gambaran petani yang menjadi responden di tiga kabupaten lokasi penelitian dipaparkan dalam Tabel 1 ketegori rendah sampai sedang; Kegiatan penyuluhan pertanian di lokasi penelitian dinilai petani pada kategori sedang sampai dengan tinggi; dan Kedinamisan kelembagaan petani sebagian besar pada kategori sedang yang menggambarkan bahwa kelembagaan petani yang ada sudah berperan namun kurang

Tabel 1. Profil Petani Menurut Lokasi dan Status Petani

\begin{tabular}{|c|c|c|c|c|c|c|c|c|}
\hline \multirow{3}{*}{$\begin{array}{l}\text { Profil } \\
\text { Petani }\end{array}$} & \multirow{3}{*}{ Satuan } & \multirow{2}{*}{\multicolumn{2}{|c|}{$\frac{\text { Lok I }}{\text { Status Petani }}$}} & \multirow{2}{*}{\multicolumn{2}{|c|}{$\begin{array}{c}\text { Lok II } \\
\text { Status Petani }\end{array}$}} & \multirow{2}{*}{\multicolumn{2}{|c|}{$\begin{array}{c}\text { Lok III } \\
\text { Status Petani }\end{array}$}} & \multirow{3}{*}{$\begin{array}{c}\text { Nilai } \\
\text { Tengah } \\
\text { Kese- } \\
\text { luruhan }\end{array}$} \\
\hline & & & & & & & & \\
\hline & & Rendah & Tinggi & $\begin{array}{l}\text { Rend } \\
\text { ah }\end{array}$ & $\underset{\mathrm{i}}{\text { Tingg }}$ & $\begin{array}{c}\text { Rend } \\
\text { ah }\end{array}$ & $\underset{\mathrm{i}}{\text { Tingg }}$ & \\
\hline 1. Usia & Tahun & 50 & 50 & 45 & 45 & 48,5 & 49 & 48,75 \\
\hline 2. Tk. Pendidikan & & & & & & & & \\
\hline a. Formal & Tahun & 9 & 12 & 9 & 9 & 6 & 9 & 9 \\
\hline b. Non-formal & Skor (3-9) & $6 \quad(67)$ & $7(78)$ & $6(67)$ & $7(78)$ & $3(33)$ & $3(33)$ & $6(67)$ \\
\hline $\begin{array}{l}\text { 3. Pengalaman } \\
\text { Usahatani }\end{array}$ & Skor (3-10) & $6(60)$ & $6(60)$ & $7(70)$ & $7(70)$ & $6(60)$ & $6(60)$ & $6(60)$ \\
\hline $\begin{array}{l}\text { 4. Tingkat } \\
\text { Pendapatan }\end{array}$ & $\begin{array}{l}\text { Rupiah } \\
(000)\end{array}$ & 800 & 1000 & 600 & 625 & 1000 & 1100 & 900 \\
\hline $\begin{array}{l}\text { 5. Tingkat Partisipasi } \\
\text { Sosial }\end{array}$ & Skor (3-10) & $5(50)$ & $6(60)$ & $6(60)$ & $6(60)$ & $6(60)$ & $6(60)$ & $6(60)$ \\
\hline
\end{tabular}

Keterangan:

- Lokasi I = Kab. Klaten, Lokasi II = Kab. Grobogan, Lokasi III = Kab. Karanganyar;

- Nilai yang disajikan dalam bentuk: median skor dan persen dari skor maks. (dalam kurung);

- Kategori: $25 \%-43 \%=$ rendah sekali, $44 \%-62 \%=$ rendah; $63 \%-81 \%=$ sedang, $82 \%-100 \%=$ tinggi;

- $\mathrm{N}=405$

Profil responden yang dapat dikemukakan adalah rentang usia petani antara 25 tahun sampai dengan 78 tahun, tingkat pendidikan formal petani berada pada statistik median 9 tahun, pendidikan non-formal pada kategori sedang, pengalaman usahatani pada kategori rendah, pendapatan petani rata-rata sebesar $\mathrm{Rp}$ 982.500, per bulan, dan tingkat partisipasi sosial petani berada pada kategori rendah. Selain itu, responden mempunyai tingkat kebutuhan pada kategori sedang yang menunjukkan tingkat kecukupan kurang; Pengalaman belajar petani berada pada kategori rendah, menunjukkan kurang optimalnya penggunaan sumber-sumber belajar yang ada, seperti: media massa, sesama petani, penyuluh, dan pedagang; Kepemimpinan lokal memberi pengaruh terhadap perilaku petani yang ditunjukkan dengan nilai tengah skor berada pada kategori tinggi; Berbagai pemangku kepentingan, yaitu: pemerintah, LSM, dan lembaga komersial, memberi pengaruh terhadap perilaku petani dalam mampu mengakomodasi kebutuhan anggota secara optimal.

\section{Efektivitas Kelembagaan Petani}

Kelembagaan petani yang ada saat ini terdiri atas: kelompok tani hamparan, kelompok tani domisili, P3A, kelompok wanita tani, kelompok pemuda tani, KUD, dan sebagainya; namun dalam penelitian ini lebih memusatkan pada tiga kelompok yang pertama. Gambaran umum kelembagaan petani yang ada di lokasi penelitian dapat digambarkan pada Tabel 2. 
Tabel 2. Deskripsi Kelembagaan Petani si Lokasi Penelitian

\begin{tabular}{|c|c|c|}
\hline No. & Aspek & Keterangan \\
\hline 1. & Fungsi (functions) & $\begin{array}{l}\text { Kelembagaan petani mempunyai banyak kegunaan (multi-purpose), } \\
\text { antara lain: pemakaian air, tanam serempak, pengendalian hama, } \\
\text { penyuluhan, arisan, penyaluran kredit/pupuk, gotong-royong, dan } \\
\text { sebagainya }\end{array}$ \\
\hline 2. & Struktur (structure) & $\begin{array}{l}\text { Struktur kelembagaan cenderung formal dengan kepengurusan yang } \\
\text { ditunjuk oleh pemerintah atau didasarkan pada pilihan anggota }\end{array}$ \\
\hline 3. & Tujuan (objectives) & $\begin{array}{l}\text { Umumnya lembaga petani selain berorientasi pada tujuan ekonomi, } \\
\text { juga berorientasi pada tujuan sosial, yaitu memupuk rasa } \\
\text { kebersamaan antara anggota. Kelembagaan belum mengarah pada } \\
\text { tujuan politik. }\end{array}$ \\
\hline 4. & $\begin{array}{l}\text { Keanggotaan } \\
\text { (membership) }\end{array}$ & $\begin{array}{l}\text { Keanggotaan didasarkan pada: hamparan usahatani, domisili } \\
\text { anggota, atau kesamaan usaha/komoditas yang dikelola. Jumlah } \\
\text { anggota tidak menentu, kadang-kadang terlalu besar untuk satu } \\
\text { kelompok }\end{array}$ \\
\hline 5. & Inisiatif (initiative) & $\begin{array}{l}\text { Kebanyakan kelembagaan petani dibentuk oleh pemerin-tah sebagai } \\
\text { upaya untuk mencapai tujuan pembangunan pertanian, hanya } \\
\text { sebagian kecil kelembagaan petani muncul dari inisiatif petani } \\
\text { sendiri }\end{array}$ \\
\hline 6. & $\begin{array}{l}\text { Pertanggungan- } \\
\text { jawab } \\
\text { (accountability) }\end{array}$ & $\begin{array}{l}\text { Kegiatan yang dilakukan dalam kelembagaan petani seringkali untuk } \\
\text { memenuhi kebijakan pemerintah dalam bidang pertanian }\end{array}$ \\
\hline
\end{tabular}

Kelembagaan petani mempunyai banyak arti penting bagi petani. Hal ini terlihat dari alasan keikutsertaan mereka dalam kegiatan kelompok tani dan manfaat yang mereka peroleh dari keikutsertaannya itu. Keberadaan lembaga petani juga diperlukan oleh pemangku kepentingan yang lain, utamanya pemerin-tah, karena menjadi tumpuan dalam pencapaian tujuan pembangunan pertanian yang lebih luas. Disadari bahwa pada saat ini secara umum lembaga petani ini belum mampu memberikan perannya secara optimal bagi kepentingan anggotanya dan memenuhi harapan bagi pihak pemerintah dalam mengemban misi pembangunan.

Efektivitas kelembagaan petani merupakan wujud keberhasilan petani dalam mengelola organisasi petani. Efektivitas kelembagaan petani mempunyai empat dimensi, yaitu: dari aspek pencapaian tujuan, aspek fungsi dan peran, aspek keinovatifan, dan aspek keberlanjutan. Tingkat efektivitas kelembagaan petani dikemukakan pada Tabel 3 .
Tingkat efektivitas kelembagaan petani sangat bervariatif namun masih berada pada kategori sedang. Terdapat kelompokkelompok tani yang berada pada kondisi 'mati suri', hanya papan nama dan rendah dinamikanya, tetapi juga terdapat kelompok-kelompok tani yang sangat dinamis dan dapat memenuhi kebutuhan anggotanya. Adanya keragaman yang tinggi tingkat efektivitas kelem-bagaan antar lokasi penelitian.

Pencapaian tujuan merupakan salah satu indikator efektivitas kelembagaan petani. Parameter-parameter yang digunakan: keberadaan dan kejelasan tujuan, kesesuaian tujuan dengan kebutuhan anggota, serta tingkat pemenuhan kebutuhan anggota. Skor pencapaian tujuan berada pada kategori sedang. Pada umumnya petani menilai bahwa kelembagaan petani yang ada, dalam bentuk kelompok tani, mempunyai tujuan untuk membantu petani anggotanya. Biasanya petani mendiskripsikan tujuan kelembagaan ini dengan berbagai ragam sehingga menunjukkan bahwa kelompok tani adalah kelembagaan yang multi tujuan. Secara umum kelembagaan petani yang ada belum mampu memenuhi 
Jurnal Penyuluhan, Maret 2009 Vol. 5 No. 1

harapan petani sesuai dengan kapasitas lembaga petani tersebut.

Fungsi dan peran lembaga merupakan kemampuan dalam mengelola informasi, tenaga kerja, modal, dan material, menyangkut fungsi: perolehan, pengaturan, pemeliharaan, pengerahan, dan pengelolaan konflik. Kelembagaan petani dinilai mampu menggerakkan sumberdaya terutama manusia, yaitu para petani sebagai tenaga kerja, sedangkan sumberdaya modal dan material masih dalam jumlah yang terbatas karena sulit untuk ketersediaan fasilitas-fasilitas fisik, kualitas sumberdaya anggota, serta keberadaan teknologi yang sesuai dalam pemecahan masalah-masalah yang dihadapi. Skor keinovatifan lembaga berada pada kategori sedang. Beberapa aspek yang dinilai kurang antara lain: keterbatasan sumberdaya yang berguna menunjang keberadaan kelembagaan, seperti: dana, fasilitas fisik, sumberdaya anggota, dan teknologi. Pembagian peran belum merata pada semua anggota karena terkonsentrasi pada pengurus. Ketergantungan pada

Tabel 3. Skor Efektivitas Kelembagaan Petani Menurut Lokasi dan Status Petani

\begin{tabular}{|c|c|c|c|c|c|c|c|c|}
\hline \multirow{2}{*}{$\begin{array}{l}\text { Indikator } \\
\text { Efektivitas } \\
\text { Kelembagaan } \\
\text { Petani }\end{array}$} & \multirow{2}{*}{ Skor } & \multicolumn{2}{|c|}{$\begin{array}{l}\text { Lok I } \\
\text { Status Petani }\end{array}$} & \multicolumn{2}{|c|}{$\begin{array}{c}\text { Lok II } \\
\text { Status Petani }\end{array}$} & \multicolumn{2}{|c|}{$\begin{array}{l}\text { Lok III } \\
\text { Status Petani }\end{array}$} & \multirow{2}{*}{$\begin{array}{c}\text { Nilai } \\
\text { Tengah } \\
\text { Keseluru- } \\
\text { han }\end{array}$} \\
\hline & & Rendah & Tinggi & Rendah & Tinggi & Rendah & Tinggi & \\
\hline $\begin{array}{l}\text { Pencapaian } \\
\text { Tujuan }\end{array}$ & $(6-24)$ & $17(71)$ & $16(67)$ & $15(63)$ & $16(67)$ & $19(79)$ & $18(75)$ & $17 \quad(71)$ \\
\hline Fungsi dan Peran & $(10-40)$ & 30.5 & $34(85)$ & $29(73)$ & $29(7$ & $32(80)$ & $33(83)$ & $32(80)$ \\
\hline & & & & & & & & $40 \quad(77)$ \\
\hline Keberlanjutan & $(8-32)$ & $25(78)$ & $26(81)$ & $24(75)$ & $25(78)$ & $29(91)$ & $28(88)$ & $25(78)$ \\
\hline
\end{tabular}

Keterangan:

- Lokasi I = Kab. Klaten, Lokasi II = Kab. Grobogan, Lokasi III = Kab. Karanganyar;

- Nilai yang disajikan dalam bentuk: median skor dan persen dari skor maks. (dalam kurung);

- Kategori: $25 \%-43 \%=$ rendah sekali, $44 \%-62 \%=$ rendah; $63 \%-81 \%=$ sedang, $82 \%-100 \%=$ tinggi;

$-\mathrm{N}=405$

dihimpun. Pada umumnya kelompok tani mempunyai forum arisan dan simpan pinjam. Beberapa diantaranya mempunyai aset bersama berupa peralatan pertanian. Kondisi yang dirasakan kurang dalam pengelolaan sumberdaya pertanian dianta-ranya: berbagai peluang kerjasama belum mampu ditangani oleh kelembagaan petani, seperti: pembelian input, pemasaran dan pengolahan hasil. Informasi-informasi pertanian belum mampu diakses oleh kelembagaan petani yang menyebabkan peran kelembagaan sebagai wahana belajar masih sangat terbatas.

Keinovatifan dalam lembaga petani mencakup aspek-aspek: peran kepemimpinan dalam lembaga, fungsi kepemimpinan dalam lembaga, keberadaan nilai-nilai yang mendasari kerjasama, pembagian peran anggota, pola kewenangan dalam lembaga, komitmen anggota terhadap lembaga, ketersediaan sumber-sumber pendanaan, pemimpin dan pengurus relatif tinggi menyebabkan kurangnya pengembangan kapasitas anggotanya

Efektivitas lembaga petani dapat dicapai apabila lembaga tersebut mampu mengembangkan diri dalam membangun komitmen anggota dan menjalin interaksi dengan sistem sosial lain yang berfungsi sebagai keberlanjutan dalam siklus kehidupan lembaga petani. Keberlanjutan dilihat dari aspek-aspek: sentimen anggota, kesadaran anggota, kekompakan anggota, kepercayaan anggota, ketersediaan bantuan luar, pola komunikasi antar anggota, dan kerjasama dengan pihak lain. Skor keberlanjutan lembaga berada pada kategori sedang. Dari skor tersebut memperlihatkan tingkat keberlanjutan masih kurang terutama pada aspek bantuan luar, komunikasi antar anggota, dan kerjasama dengan pihak lain. 
Jurnal Penyuluhan, Maret 2009 Vol. 5 No. 1

Sebagian besar petani melihat kelembagaan petani sebagai wahana belajar, yaitu: untuk mendapatkan informasi pertanian/ menambah wawasan dan pengalaman; dan sarana untuk meningkatkan usaha yang meliputi: peningkatan produksi UT/penerimaan/pendapatan/kesejahteraan.

Pandangan ini menunjukkan harapan (tujuan jangka panjang) petani untuk menjamin kelangsungan hidupnya sebagai petani. Selain itu, terlihat adanya kesadaran petani untuk dapat memecahkan berbagai permasalahan yang dihadapi melalui keberadaan kelembagaan petani. Hanya sebagian kecil dari petani yang mengungkapkan alasan bersifat pragmatis, yaitu untuk mendapatkan bantuan atau fasilitas yang lain.

\section{Faktor-faktor yang Mempengaruhi Efektivitas Kelembagaan Petani}

Faktor-faktor yang mempengaruhi efektivitas kelembagaan petani, seperti dinyatakan dalam hipotesis, yaitu: tingkat efektivitas kelembagaan petani dipengaruhi secara nyata oleh tingkat partisipasi petani dalam kelembagaan, kapasitas petani, status sosial ekonomi, kebutuhan petani, pengalaman belajar, kepe-mimpinan lokal, peran pihak luar, dan kualitas penyuluhan. Untuk menganalisis faktor-faktor tersebut digunakan analisis jalur (path analysis). Hasil uji ini disajikan pada Tabel 4.

Hubungan antar variabel dapat dijelaskan pada koefisien lintas sebagai berikut:

Kapasitas petani dan tingkat partisipasi petani berpengaruh positif nyata ter-hadap tingkat efektivitas kelembagaan petani dengan nilai koefisien lintas masing-masing sebesar 0,232 dan 0,574. Pendidikan formal petani berpengaruh negatif nyata terhadap tingkat efektivitas kelembagaan petani dengan nilai koefisien lintas sebesar -0.105 .

Tingkat kebutuhan petani, pengaruh kepemimpinan lokal, peran pihak luar, dan kualitas penyuluhan pertanian berpengaruh positif nyata terhadap tingkat efektivitas kelembagaan petani dengan nilai koefisien lintas masing-masing sebesar 0.121, 0.062, 0.117 , dan 0.143 .

Tabel 4. Faktor-Faktor yang Mempengaruhi Efektivitas Kelembagaan Petani

\begin{tabular}{|c|c|c|c|c|c|c|}
\hline \multirow{3}{*}{ Variabel Bebas } & \multicolumn{6}{|c|}{ Variabel Tak Bebas } \\
\hline & \multicolumn{2}{|c|}{ Kapasitas Individu (Y1) } & \multicolumn{2}{|c|}{$\begin{array}{l}\text { Partisipasi Petani } \\
\text { dalam Kelembagaan } \\
\text { (Y2) }\end{array}$} & \multicolumn{2}{|c|}{$\begin{array}{l}\text { Efektivitas } \\
\text { Kelembagaan Petani } \\
\text { (Y3) }\end{array}$} \\
\hline & $\mathrm{p}_{\mathrm{xY} 1 \mathrm{xi}}$ & $p$ & $\mathrm{p}_{\mathrm{xY} 2 \mathrm{xi}}$ & $p$ & $\mathrm{p}_{\mathrm{xY} 3 \mathrm{xi}}$ & $p$ \\
\hline $\begin{array}{l}\text { Pendidikan Formal } \\
\text { (X1.2) }\end{array}$ & $0,113 * *)$ & $(0,004)$ & 0,020 & $(0,636)$ & $-0.105 * *)$ & $(0,002)$ \\
\hline $\begin{array}{l}\text { Pendidikan Non- } \\
\text { formal (X1.3) }\end{array}$ & $\left.0,075^{*}\right)$ & $(0,051)$ & $-0,033$ & $(0,425)$ & -0.028 & $(0,403)$ \\
\hline $\begin{array}{l}\text { Pengalaman Usahatani } \\
\text { (X1.4) }\end{array}$ & $0,120 * *)$ & $(0,001)$ & 0,016 & $(0,686)$ & 0.009 & $(0,791)$ \\
\hline Pendapatan (X1.5) & $\left.0,116^{* *}\right)$ & $(0,001)$ & $0,071 *)$ & $(0,075)$ & 0.001 & $(0,981)$ \\
\hline $\begin{array}{l}\text { Partisipasi Sosial } \\
\text { (X1.6) }\end{array}$ & $-0,014$ & $(0,719)$ & 0,084 & $(0,041)$ & -0.033 & $(0,314)$ \\
\hline $\begin{array}{l}\text { Kebutuhan Petani } \\
\text { (X2) }\end{array}$ & $0,063 *)$ & $(0,100)$ & $0,252 * *)$ & $(0,000)$ & $0.121 * *)$ & $(0,000)$ \\
\hline $\begin{array}{l}\text { Pengalaman Belajar } \\
\text { (X3) }\end{array}$ & $0,341 * *)$ & $(0,000)$ & $-0,039$ & $(0,451)$ & -0.067 & $(0,101)$ \\
\hline $\begin{array}{l}\text { Kepemimpinan Lokal } \\
\text { (X4) }\end{array}$ & $0,297 * *)$ & $(0,000)$ & 0.059 & $(0,169)$ & $0.062 *)$ & $(0,072)$ \\
\hline Peran Pihak Luar (X5) & 0,053 & $(0,169)$ & $-0,003$ & $(0,944)$ & $0.117 * *)$ & $(0,000)$ \\
\hline $\begin{array}{l}\text { Kualitas Penyuluhan } \\
\text { (X6) }\end{array}$ & $0,133 * *)$ & $(0,001)$ & $0,339 * *)$ & $(0,000)$ & $0.143 * *)$ & $(0,000)$ \\
\hline $\begin{array}{l}\text { Kapasitas Individu } \\
\text { (Y1) }\end{array}$ & & & $0,232 * *)$ & $(0,000)$ & $0.124 * *)$ & $(0,006)$ \\
\hline $\begin{array}{l}\text { Partisipasi Petani dlm } \\
\text { Kelembagaan (Y2) }\end{array}$ & & & & & $0.574 * *)$ & $(0,000)$ \\
\hline
\end{tabular}




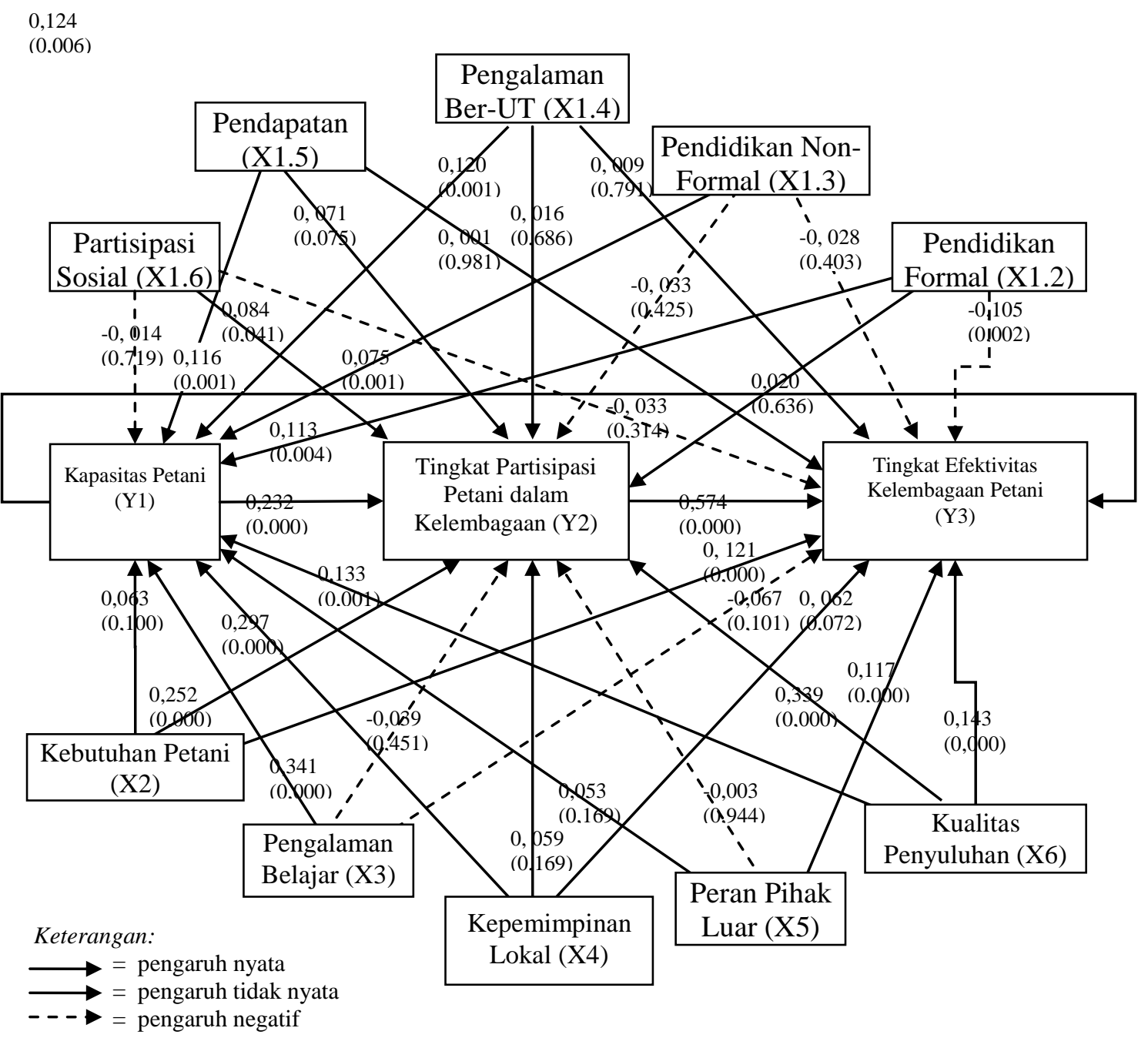

Gambar 2. Model Hubungan antara Faktor-faktor yang Mempengaruhi Efektivitas Kelembagaan Petani

Analisis lintas terhadap hubungan kausal variabel-variabel yang berpengaruh terhadap tingkat efektivitas kelembagaan petani menunjukkan:

- Pendidikan formal petani, pengalaman belajar, dan peran pihak luar mempunyai pengaruh langsung yang lebih besar (80 persen, 51 persen, dan 94 persen) terhadap tingkat efektivitas kelembagaan petani.

- Pendapatan petani, partisipasi sosial, tingkat kebutuhan petani dan kualitas penyuluhan pertanian berpengaruh tidak langsung relatif besar ( 73 persen, 58 persen, 53 persen dan 60 persen) terhadap terhadap tingkat efektivitas kelembagaan petani melalui partisipasi petani dalam kelembagaan petani.

- Pengalaman berusahatani berpengaruh tidak langsung relatif besar (45 persen) terhadap terhadap tingkat efektivitas kelembagaan petani melalui kapasitas petani.

Bentuk hubungan antar variabel dalam penelitian dapat dilihat pada Gambar 2.

Partisipasi petani dalam kelembagaan berpengaruh positif nyata terhadap efektivitas kelembagaan petani. Sejalan dengan pemikiran IADB (2001) bahwa partisipasi dapat menguatkan kapasitas lembaga lokal, 
Jurnal Penyuluhan, Maret 2009 Vol. 5 No. 1

seperti: ketrampilan manajemen, kemandirian, kepercayaan, transparansi, akuntabilitas, dan akses terhadap sumberdaya luar. Partisipasi petani petani dalam kelembagaan petani mencerminkan keberadaan modal sosial pada masyarakat petani di pedesaan. Keberadaan modal sosial yang kuat menggambarkan berkembangnya jaringan kerja, norma, dan kepercayaan sosial, yang memfasilitasi adanya koordinasi dan kerjasama yang saling menguntungkan (Krishna, 2000). Berdasarkan pernyataan ter-sebut dapat dipahami bahwa partisipasi petani yang tinggi akan mendorong pada pencapaian efektivitas kelembagaan yang tinggi juga.

Kapasitas petani berpengaruh positif secara nyata, baik secara langsung (48 persen) maupun tidak langsung (52 persen) melalui partisipasi petani dalam kelembagaan, terhadap efektivitas kelembagaan petani. Kondisi ini dapat dijelas-kan bahwa secara langsung dalam suatu lembaga memerlukan masukanmasukan, salah satunya adalah sumberdaya manusia (Esman, 1986). Kapasitas petani merupakan salah satu indikator kualitas sumberdaya petani. Agar dapat men-jalankan fungsi dan perannya dengan baik, serta mengembangkan norma-norma ke arah yang lebih baik maka suatu kelembagaan memerlukan individu-individu yang mempunyai kapasitas yang semakin besar. Melalui proses partisipasi, kapasitas petani semakin meningkat sejalan dengan meningkatnya temuan dan pembelajaran sosial yang terjadi pada diri petani sehingga pengetahuan, wawasan, dan kesadarannya meningkat yang pada akhirnya dapat menciptakan komitmen terhadap kelembagaan petani.

Kualitas penyuluhan pertanian mempunyai pengaruh total yang relatif besar terhadap tingkat efektivitas kelembagaan petani. Eksistensi suatu kelembagaan memerlukan masukan-masukan berupa: kepemimpinan, doktrin, program, sumberdaya, dan struktur internal (Esman, 1986). Menurut Sumardjo (2003) agen pembaharu (penyuluh) cukup berperan secara efektif sebagai pengembang kepemimpinan dan kesadaran kritis dalam masyarakat atas pentingnya peran kelompok. Salah satu tujuan kegiatan penyuluhan adalah meningkatkan kapasitas lembaga, kelompok tani, sehingga menjadi lebih efektif. Lembaga petani yang efektif (Esman, 1986; Jiri Nehnevajsa dalam Eaton, 1986; Sumardjo, 2003; Wileden, 1970) adalah: (a) Kelembagaan petani mampu kebutuhan anggota; (b) Kelembagaan petani dapat sumberdaya lokal (tenaga kerja, modal, material, dan informasi) dengan efisien, (c) Kelembagaan petani mampu mengembangkan struktur, kepemimpinan, norma-norma, dan (d) Kelembagaan petani mampu mengembangkan solidaritas dan jaringan kerjasama.

Kebutuhan petani lebih berpengaruh secara tidak langsung, yaitu melalui partisipasi petani dalam kelembagaan petani, terhadap efektivitas kelembagaan petani.

\section{Model Partisipasi Petani untuk Meningkatkan Efektivitas Kelembagaan Petani}

Kaitan antara tingkat partisipasi petani dalam kelembagaan petani dengan tingkat efektivitas kelembagaan petani, dirumuskan dalam hipotesis, yaitu: Tingkat efektivitas kelembagaan petani dipengaruhi secara nyata oleh partisipasi petani dalam kelembagaan petani yang ditunjukkan oleh intensitas partisipasi dan kualitas partisipasi. Hipotesis ini diuji dengan analisis jalur (path analysis). Hasil uji ini disajikan pada Tabel 5

Hubungan antar variabel dapat dijelaskan pada koefisien lintas sebagai berikut:

(a) Variabel partisipasi dalam kelembagaan dapat dijelaskan melalui subvariabel intensitas partisipasi dan kualitas partisipasi dengan nilai koefisien lintas masingmasing sebesar 0.543, dan 0.308.

(b) Intensitas partisipasi petani dalam kelembagaan dan kualitas partisipasi petani dalam kelembagaan berpengaruh positif nyata terhadap efektivitas kelembagaan petani dengan nilai koefisien lintas masing-masing sebesar 0.517 , dan 0.597 . 
Jurnal Penyuluhan, Maret 2009 Vol. 5 No. 1

Analisis lintas menunjukkan bahwa intensitas partisipasi petani dalam kelembagaan dan kualitas partisipasi petani dalam kelembagaan berpengaruh langsung yang lebih besar (55 persen dan 72 persen) terhadap tingkat efektivitas kelembagaan petani. Kedua kegiatan-kegiatan pembangunan (Oakley et al. dalam Kumar (2002). Mendasarkan pernyataan ini maka peningkatan partisipasi petani dalam kelembagaan, baik intensitas maupun kualitasnya, akan menorong tercapainya efektivitas kelembagaan yang semakin tinggi.

Tabel 5. Koefisien Lintas Variabel Bebas Partisipasi Petani dalam Kelembagaan Terhadap Variabel Tak Bebas Efektivitas Kelembagaan Petani

\begin{tabular}{|c|c|c|c|c|}
\hline \multirow{3}{*}{ Variabel Bebas } & \multicolumn{4}{|c|}{ Variabel Tak Bebas } \\
\hline & \multicolumn{2}{|c|}{$\begin{array}{l}\text { Partisipasi Petani dalam } \\
\text { Kelembagaan (Y2) }\end{array}$} & \multicolumn{2}{|c|}{$\begin{array}{l}\text { Efektivitas Kelembagaan } \\
\text { Petani (Y3) }\end{array}$} \\
\hline & $\mathrm{p}_{\mathrm{xY} 2 \mathrm{xi}}$ & $p$ & $\mathrm{p}_{\mathrm{xY} 3 \mathrm{xi}}$ & $p$ \\
\hline Intensitas partisipasi (Y2.1) & $0.543 * *)$ & $(0,000)$ & $0.517 * *)$ & $(0,000)$ \\
\hline Kualitas partisipasi (Y2.2) & $0.308 * *)$ & $(0,000)$ & $0.597 * *)$ & $(0,000)$ \\
\hline $\begin{array}{l}\text { Partisipasi Petani dalam } \\
\text { Kelembagaan (Y2) }\end{array}$ & & & $0.766^{* *)}$ & $(0,000)$ \\
\hline
\end{tabular}

Keterangan: $* *)$ Nyata pada $\alpha=0.01$

variabel itu juga mempunyai pengaruh total yang besar. Bentuk hubungan antar variabel dalam penelitian dapat dilihat pada Gambar 3 .

Gambaran hubungan tersebut dapat dijelaskan bahwa partisipasi petani dalam kelembagaan berpengaruh terhadap efektivitas kelembagaan petani. Semakin tinggi partisipasi petani dalam kelembagaan petani, semakin tinggi efektivitas kelembagaan petani. Baik intensitas partisipasi maupun kualitas partisipasi mereka dalam kelembagaan akan mendorong pada peningkatan efektivitas kelembagaan. Partisipasi masyarakat diyakini dapat menguatkan kapasitas lembaga lokal. Dengan partisipasi akan seseorang akan memperoleh nilai tambah, seperti: keterampilan manajemen, kemandirian, kepercayaan, transparansi, akuntabilitas, dan akses terhadap sumberdaya luar (IADB, 2001). Di samping itu, partisipasi petani dalam kelembagaan merupakan bentuk tanggungjawab sosial petani.

Partisipasi masyarakat dalam berbagai kegiatan, termasuk dalam kelembagaan pertanian, akan mendorong efisiensi (eficiency) dan efektif (effectiveness) dalam penggunaan sumberdaya yang tersedia karena petani merasa mengambil tanggungjawab; dapat meningkatkan kesadaran, kepercayaan diri, dan pengawasan atas proses pembangunan; sebagai sebuah prasyarat bagi keberlanjutan suatu
Partisipasi individu petani dalam kelembagaan akan menghasilkan pengalaman belajar yang berharga bagi petani. Petani dapat meningkatkan temuan-temuan dan proses pembelajaran sosial, sehingga dapat menciptakan komitmen terhadap perubahan sosial. Partisipasi petani dalam kelembagaan timbul karena pengalaman belajar serta tumbuhnya kesadaran untuk membangun kerjasama dan kepercayaan sehingga mendorong penguatan keberadaan lembaga. Di sisi lain, keberhasilan lembaga ditandai dengan pencapaian tujuan sosial ekonomis, yaitu: (a) kemampuan untuk mempertahankan kelangsungan hidupnya; (b) inovatif (mengadakan pembaharuan) yang dipandang oleh lingkungannya sebagai memiliki nilai intrinsik; dan (c) membangun pola yang menjadi normatif bagi lain-lain kesatuan sosial dalam sistem sosial yang lebih besar (Jiri Nehnevajsa dalam Eaton, 1986). Keberhasilan lembaga ini akan mendorong atau menumbuhkan kemauan petani untuk berpartisipasi. Hal ini bisa terjadi didasarkan perilaku rasional petani bahwa partisipasi adalah sebuah fungsi dari manfaat yang akan diperoleh. 




Gambar 3. Model Tingkat Partisipasi Petani Dalam Meningkatkan Efektivitas Kelembagaan Petani

\section{KESIMPULAN}

Dari pembahasan dapat ditarik beberapa kesimpulan sebagai berikut: (1) Efektivitas kelembagaan petani berada pada ketegori sedang, artinya kelembagaan petani yang ada kurang mampu dalam memenuhi kebutuhan anggotanya, peran dalam pengelolaan sumberdaya kurang maksimal, kesadaran untuk kerjasama sudah ada namun kurang mampu mengerahkan potensi yang dimiliki, serta kurang dalam mengembangkan jaringan kerjasama dengan pihak lain; (2) Efektivitas kelembagaan petani secara langsung dipengaruhi oleh tingkat partisipasi petani dalam kelembagaan, peran pihak luar, pendidikan formal petani, dan pengaruh kepemimpinan lokal. Pendapatan petani, kualitas penyuluhan, partisipasi sosial, kebutuhan petani, dan kapasitas petani berpengaruh secara tidak langsung terhadap tingkat efektivitas kelembagaan petani melalui partisipasi petani dalam kelembagaan petani. Pengalaman berusahatani berpengaruh secara tidak langsung terhadap efektivitas kelembagaan petani melalui kapasitas petani; (3) Kualitas penyuluhan pertanian memberikan pengaruh positif terhadap kapasitas petani dan tingkat partisipasi petani dalam kelembagaan petani. Untuk mencapai hasil optimal maka perlu diupayakan kualitas penyuluhan yang semakin memadai dalam menjawab tantangan pertanian di masa mendatang. Peningkatan kualitas penyuluhan pertanian mencakup tiga aspek, yaitu: kompetensi penyuluh, pendekatan, serta kelembagaan yang mendukung.

\section{DAFTAR PUSTAKA}

Anwar, A. 2003. Pembangunan Kelembagaan Wilayah dalam Rangka Pe-ngelolaan Sumberdaya Alam: Kerangka Pendekatan Managemen Ekosistem. Makalah Kuliah Umum Desember 2003.

Eaton, J. W. 1986. "Petunjuk bagi Perumusan Teori Pembangunan" dalam Pembangunan Lembaga dan Pembangunan Nasional: dari Konsep ke Aplikasi. Editor J.W. Eaton. UI Press. Jakarta.

Esman, M. J. 1986. "Unsur-unsur dari Pembangunan Lembaga" dalam Pembangunan Lembaga dan Pembangunan 
Jurnal Penyuluhan, Maret 2009 Vol. 5 No. 1

Nasional: dari Konsep ke Aplikasi. Editor J.W. Eaton. UI Press. Jakarta.

Garkovich, L. E. 1989. “Local Organizations and Leadership in Commu-nity Development" dalam Community Development in Perspective. Edi-tor James A. Christenson dan Jerry W. Robinson, Jr. Iowa: Iowa State University Press Iowa.

IADB. 2001. Resource Book On Participation. Inter-American Development Bank. http://www.iadb. org/exr/english/POLICIES/participate/i ndex.htm

Krishna, A. 2000. "Creating and Harnessing Social Capital" dalam Social Capital: A Multifaceted Perspective. Diedit oleh Partha Dasgupta dan Ismail Serageldin. The World Bank. Washington.

Kumar, Somesh. 2002. Methods for Community Participation: A Complete
Guide for Practitioners. London: ITDG Publishing.

Uphoff, Norman Thomas. 1986. Local Institutional Development: An Analytical Sourcebook With Cases. Kumarian Press.

Yustika, A. E. 2006. Ekonomi Kelembagaan: Definisi, Teori, dan Strategi. Malang: Banyumedia Publishing.

Sumardjo. 2003. "Kepemimpinan dan Pengembangan Kelembagaan Pedesaan: Kasus Kelembagaan Ketahanan Pangan" dalam Membentuk Pola Perilaku Manusia Pembangunan. Penyunting Ida Yustina dan Ajad Sudradjat. IPB Press. Bogor. Hal 151 $-169$.

Wileden, Arthur F. 1970. Community Development: The Dynamics of Planned Change. New York: The Bedminster Press. 